\title{
Control of Trace Metal Emissions During Coal Combustion
}

\author{
Quarterly Report \\ April 1 - June 30, 1997
}

\author{
By \\ Thomas C. Ho
}

Work Performed Under Contract No.: DE-FG22-94PC94221

\author{
For \\ U.S. Department of Energy \\ Office of Fossil Energy \\ Federal Energy Technology Center \\ P.O. Box 880 \\ Morgantown, West Virginia 26507-0880 \\ By \\ Lamar University \\ Beaumont, Texas 77710
}




\section{Disclaimer}

This report was prepared as an account of work sponsored by an agency of the United States Government. Neither the United States Government nor any agency thereof, nor any of their employees, makes any warranty, express or implied, or assumes any legal liability or responsibility for the accuracy, completeness, or usefulness of any information, apparatus, product, or process disclosed, or represents that its use would not infringe privately owned rights. Reference herein to any specific commercial product, process, or service by trade

name, trademark, manufacturer, or otherwise does not necessarily constitute or imply its endorsement, recommendation, or favoring by the United States Government or any agency thereof. The views and opinions of authors expressed herein do not necessarily state or reflect those of the United States Government or any agency thereof. 


\title{
TECHNICAL PROGRESS REPORT
}

\section{(April 1, 1997 through June 30, 1997)}

\author{
Prepared
}

for the Project

CONTROL OF TRACE METAL EMISSIONS DURING COAL COMBUSTION

Thomas C. Ho

Department of Chemical Engineering

Lamar University

Beaumont, Texas

July 1997

\author{
Prepared by \\ LAMAR UNIVERSITY \\ Beaumont, Texas 77710 \\ for the \\ U.S. DEPARTMENT OF ENERGY \\ PITTSBURGH ENERGY TECHNOLOGY CENTER
}

under Grant No. DE-FG22-94PC94221 --12 
Disclaimer. This report was prepared as an account of work sponsored by an agency of the United States Government. Neither the United States Government nor any agency thereof, nor any of their employees, makes any warranty, express or implied, or assumes any legal liability or responsibility for the accuracy, completeness, or usefulness of any information, apparatus, product, or process disclosed, or represents that its use would not infringe privately owned right. Reference herein to any specific commercial product, process, or service by trade name, trademark, manufacturer, or otherwise does not necessarily constitute or imply its endorsement, recommendation, or favoring by the United States Government or any agency thereof. The views and opinions of authors expressed herein do not necessarily state or reflect those of the United States Government or any agency thereof.

Measurement Units. All reports to be delivered under this instrument shall use the SI Metric System of Units as the primary units of measure. When reporting units in all reports, primary SI units shall be followed by their U.S. Customary Equivalents in Parentheses ( ). The grantee shall insert the text of this clause, including this paragraph, in all subgrants or subcontracts under this grant. Note: SI is an abbreviation for "Le Systeme International d'Unites." 
TECHNICAL PROGRESS REPORT

April 1, 1997 through June 30, 1997 $\begin{array}{ll}\text { Project Title: } & \text { CONTROL OF TRACE METAL EMISSIONS DURING COAL } \\ \text { COMBUSTION }\end{array}$

DOE Grant Number: $\quad$ DE-FG22-94PC94221

Principal Investigator: Thomas C. Ho, Lamar University

DOE Project Officer: $\quad$ Mike Baird, PETC

\begin{abstract}
Emissions of toxic trace metals in the form of metal fumes or submicron particulates from a coalfired combustion source have received greater environmental and regulatory concern over the past years. Current practice of controlling these emissions is to collect them at the cold-end of the process by air-pollution control devices (APCDs) such as electrostatic precipitators and baghouses. However, trace metal fumes may not always be effectively collected by these devices because the formed fumes are extremely small.

The proposed research is to explore the opportunities for improved control of toxic trace metal emissions, alternatively, at the hot-end of the coal combustion process, i.e., in the combustion chamber. The technology proposed is to prevent the metal fumes from forming during the process, which would effectively eliminate the metal emission problems. Specifically, the technology is to employ suitable sorbents to (1) reduce the amount of metal volatilization during combustion and (2) capture volatilized metal vapors. The objectives of the project are to demonstrate the technology and to characterize the metal capture process during coal combustion in a fluidized bed combustor.
\end{abstract}

The project was started on July 1, 1994 and this is the twelfth quarterly technical progress report. Specifically, the following progress has been made during this performance period from April 1, 1997 through June 30, 1997:

1. Metal Capture Experiments Continued - Additional combustion experiments involving seven different coal samples were carried out to obtain more statistically representative results.

2. Additional Results Obtained - Additional metal capture results were obtained and were added into the existing database. The metals involved included lead, cadmium, chromium, arsenic, and selenium.

3. Paper Presented - A paper, entitled "Metal Vaporization and Metal Binding by Additives or Sorbents During High Temperature Thermal Treatment," was presented at the 1997 International Incineration Conference held in Oakland, CA, May 12-16, 1997.

4. Presentation Accepted - An abstract, entitled "Effect of Temperature on Mercury Desorption from Sorbents in a Packed Bed Absorber," has been accepted for presentation at the 1997 AIChE Annual Meeting to be held in Los Angeles, CA, November 16-21, 1997. 


\section{TABLE OF CONTENTS}

page

EXECUTIVE SUMMARY 1

$\begin{array}{ll}\text { INTRODUCTION } & 2\end{array}$

$\begin{array}{ll}\text { SCIENTIFIC DISCUSSION } & 2\end{array}$

$\begin{array}{ll}\text { EXPERIMENTAL } & 3\end{array}$

RESULTS AND DISCUSSION 4

$\begin{array}{lr}\text { CONCLUSIONS } & 6\end{array}$

$\begin{array}{ll}\text { NOTATION } & 7\end{array}$

$\begin{array}{lr}\text { REFERENCES } & 8\end{array}$

TABLES

Table 1. Sulfur, Chlorine and Target Metals in Coal Samples 9

Table 2. Major Composition, Trace Metal Concentration and Fluidization Properties of the Three Tested Sorbents 10

Table 3. Experimental Parameters and Operating Conditions 11

Table 4. Equilibrium Simulation Results for Lead with or without Sulfur $\quad 12$

Table 5. Equilibrium Simulation Results for Cadmium with or without Sulfur 13

Table 6. Percentage Lead Capture by Bed Sorbents $\left(\psi_{\mathrm{b}}\right) \quad 14$

Table 7. Percentage Cadmium Capture by Bed Sorbents $\left(\psi_{\mathrm{b}}\right)$

Table 8. $\quad$ Percentage Chromium Capture by Bed Sorbents $\left(\psi_{\mathrm{b}}\right) \quad 16$

Table 9. Percentage Arsenic Capture by Bed Sorbents $\left(\psi_{\mathrm{b}}\right) \quad 17$

$\begin{array}{lll}\text { Table 10. } & \text { Percentage Selenium Capture by Bed Sorbents }\left(\psi_{\mathrm{b}}\right) & 18\end{array}$

$\begin{array}{ll}\text { FIGURES } & 19\end{array}$ 


\section{EXECUTIVE SUMMARY}

Toxic (or potentially toxic) trace metallic elements such as barium, beryllium, boron, cadmium, chromium, lead, mercury, nickel, selenium, strontium, vanadium, zinc and zirconium are usually contained in coal in various forms. These metals will either stay in the ash or be vaporized during high temperature combustion. Portions of the vaporized metals may eventually be emitted from a combustion system. Most of the emitted metals will be in the form of metal fumes or particulates with diameters less than 1 micron and are potentially hazardous to the environment. The U.S. EPA has reported that metals account for almost all of the identified risks from waste incineration systems.

Concern over toxic trace metal emissions from coal-fired combustion sources is growing, especially as the result of the passage of the 1990 Clean Air Act Amendments (CAAA). To address the concern, the U.S. DOE has recently co-sponsored a workshop jointly with the Electric Power Research Institute (EPRI) and the Energy and Environmental Research Center (EERC) on Trace Elements Transformations in Coal-Fired Power Plants. The objective of the workshop was to evaluate the current level of understanding on metal behavior during coal combustion and to identify potential technologies for improved metal emission control.

Current practice of controlling trace metal emissions during coal combustion employs conventional air pollution control devices (APCDs), e.g., venturi scrubbers, electrostatic precipitators, baghouses etc., to collect fly ash and metal fumes. This type of control is essentially a cold-end technology because metals are allowed to vaporize and condense before being collected. The control may not always be effective on metal fumes due to their extremely fine sizes.

An alternative technology for metal emission control is to minimize the formation of metal fumes at the hot-end of the coal combustion process, i.e., in the combustion chamber. The technology proposed is to prevent the metal fumes from forming during the process, which would effectively eliminate the metal emission problems. Specifically, the technology is to employ suitable sorbents to (1) reduce the amount of metal volatilization during combustion and (2) capture volatilized metal vapors. The objectives of the project are to demonstrate the technology and to characterize the metal capture process during coal combustion in a fluidized bed combustor.

The project was started on July 1, 1994 and this is the twelfth quarterly technical progress report. Specifically, the following progress has been made during this performance period from April 1, 1997 through June 30, 1997:

1. Metal Capture Experiments Continued - Additional combustion experiments involving seven different coal samples were carried out to obtain more statistically representative results.

2. Additional Results Obtained - Additional metal capture results were obtained and were added into the existing database. The metals involved included lead, cadmium, chromium, arsenic, and selenium. 
3. Paper Presented - A paper, entitled "Metal Vaporization and Metal Binding by Additives or Sorbents During High Temperature Thermal Treatment," was presented at the 1997 International Incineration Conference held in Oakland, CA, May 12-16, 1997.

4. Presentation Accepted - An abstract, entitled "Effect of Temperature on Mercury Desorption from Sorbents in a Packed Bed Absorber," has been accepted for presentation at the 1997 AIChE Annual Meeting to be held in Los Angeles, CA, November 16-21, 1997.

\section{INTRODUCTION}

Toxic trace metallic elements such as arsenic, cadmium, chromium, lead, mercury, and selenium are usually contained in coal in various forms and trace amounts. Portions of these metals may eventually be emitted from a combustion system in the form of metal fumes or particulates with diameters less than 1 micron, which are potentially hazardous to the environment (Davidson et al., 1974). Current practice of controlling trace metal emissions during coal combustion employs conventional air pollution control devices (APCDs), such as electrostatic precipitators and baghouses, to collect fly ash and metal fumes. The control may not always be effective on metal fumes due to their extremely fine sizes (Oppelt, 1987).

Concern over toxic trace metal emissions from coal-fired combustion sources is growing, especially as the result of the passage of the 1990 Clean Air Act Amendments (CAAA) where eleven metallic elements, i.e., antimony, arsenic, beryllium, cadmium, chromium, cobalt, lead, manganese, mercury, nickel, and selenium are listed as potential hazardous air pollutants. This study is to explore the opportunities for improved control of toxic trace metal emissions from coal-fired combustion systems. Specifically, the technology proposed is to employ suitable sorbents to (1) reduce the amount of metal volatilization and (2) capture volatilized metal vapors during fluidized bed coal combustion. The objectives of the project were to demonstrate the capture process, identify effective sorbents, and characterize the capture efficiency.

\section{SCIENTIFIC DISCUSSION}

\section{Metal-Sorbent Reactions}

Chemical absorption reactions between metal vapors and a variety of sorbents at high temperatures have been observed both in a packed bed and in a fluidized bed (see, e.g., Punjak et al., 1989; Uberol and Shadman, 1990; Ho et al., 1992, 1994). The following reactions between metals and sorbent constituents have been confirmed both theoretically and experimentally:

$$
\begin{aligned}
& 2 \mathrm{PbO}+\mathrm{SiO}_{2}---->\mathrm{Pb}_{2} \mathrm{SiO}_{4}(\mathrm{~s}) \\
& \mathrm{CdO}+\mathrm{SiO}_{2}---->\mathrm{CdSiO}_{3}(\mathrm{~s}) \\
& \mathrm{CdO}+\mathrm{Al}_{2} \mathrm{O}_{3}---->\mathrm{CdAl}_{2} \mathrm{O}_{4}(\mathrm{~s}) \\
& \mathrm{PbCl}_{2}+\mathrm{Al}_{2} \mathrm{O}_{3}: 2 \mathrm{SiO}_{2}+\mathrm{H}_{2} \mathrm{O}---->\mathrm{PbO}: \mathrm{Al}_{2} \mathrm{O}_{3}: 2 \mathrm{SiO}_{2}(\mathrm{~s})+2 \mathrm{HCl}(\mathrm{g}) \\
& \mathrm{CdCl}_{2}+\mathrm{Al}_{2} \mathrm{O}_{3}+\mathrm{H}_{2} \mathrm{O}---->\mathrm{CdAl}_{2} \mathrm{O}_{4}(\mathrm{~s})+2 \mathrm{HCl}(\mathrm{g})
\end{aligned}
$$


Note that the technology of metal capture by sorbents during fluidized bed coal combustion has never been evaluated. Due to the trace concentration and the nonuniformity nature of metals in coal, statistical approaches are essential in the evaluation.

\section{Chemical Equilibrium}

Equilibrium composition represents the most stable chemical composition within a system under a specific state. Thermodynamically, this composition is corresponding to the one where the system's free energy is minimized. The calculated equilibrium composition would reveal the preferred chemical speciation under a specific state, which in turn, suggest potential chemical reactions which may occur within the system. In this study, combustion equilibrium was calculated using a PC-based computer software package (Ho, 1996) especially developed for predicting equilibrium compositions during fuel or waste combustion.

\section{EXPERIMENTAL}

\section{Facilities and Procedure}

Metal capture experiments were carried out semi-batchwise in a $25.4 \mathrm{~mm}$ (1") OD quartz fluidized bed coal combustor enclosed in an electric furnace. A schematic diagram of the fluidized bed coal combustion system is shown in Figure 1. Seven coal samples from the Illinois Basin Coal Sample Bank (IBCSB) were tested in the experiments. The concentration of sulfur, chlorine, and the target metals in these samples is summarized in Table 1. The sorbents tested included bauxite, zeolite and lime. Their chemical composition and the corresponding minimum fluidization velocity $\left(\mathrm{U}_{\mathrm{mf}}\right)$ at $900^{\circ} \mathrm{C}$ are listed in Table 2.

In an experimental run, a bed of sorbent (normally $6 \mathrm{~cm}$ bed height) was preheated to the desired temperature under the designed operating conditions (normally $900^{\circ} \mathrm{C}$ and $3 \mathrm{U}_{\mathrm{mf}}$ ). A predetermined amount of coal (normally $60 \mathrm{~g}$ ) was then charged in the bed at a constant feed rate for combustion. After the combustion was completed, the bed residue including sorbent and ash was discharged and separated for analysis of metal concentration. The experimental parameters and operating conditions are summarized in Table 3.

Metal concentration in coal, original sorbent, and combustor residue was determined by an atomic absorption spectrophotometer. An HF modified EPA Method 3050 was used to digest metals from the sorbent, which involves the use of $\mathrm{HNO}_{3}, \mathrm{HCl}$ and $\mathrm{HF}$ acids (Gao and Silcox, 1993). Toxicity Characteristics Leaching Procedure (TCLP) tests were also performed to determine the leachability of the captured metals from sorbents.

\section{Data Analysis}

Specific Capture Capacity $(\phi)$ - This is defined to be the amount of metal captured by a unit mass of bed (or fly ash) sorbent. It was calculated as:

$$
\phi_{\mathrm{b}}=\mathrm{C}_{\mathrm{b}}-\mathrm{C}_{\mathrm{o}}
$$


or

$$
\phi_{\mathrm{f}}=\mathrm{C}_{\mathrm{f}}-\mathrm{C}_{\mathrm{o}}
$$

Percent Capture $(\psi)$ - This is defined to be the percent of metal captured by fluidized bed sorbents (or fly ash sorbents) relative to the total amount of metal charged. It was calculated as:

$$
\psi_{\mathrm{b}}=\frac{\phi_{\mathrm{b}} \times \mathrm{W}_{\mathrm{b}}}{\mathrm{C}_{\mathrm{c}} \times \mathrm{W}_{\mathrm{c}}} \times 100 \%
$$

or

$$
\psi_{\mathrm{f}}=\frac{\phi_{\mathrm{f}} \times \mathrm{W}_{\mathrm{f}}}{\mathrm{C}_{\mathrm{c}} \times \mathrm{W}_{\mathrm{c}}} \times 100 \%
$$

All chemical symbols used in the equations are defined at the end of this report.

\section{RESULTS AND DISCUSSION}

\section{Simulation Results}

Two typical sets of simulation results indicating potential metal-sorbent reactions and the effect of sulfur on metal capture by sorbents are shown in Tables 4 and 5 for lead and cadmium, respectively. The corresponding elemental compositions and combustion conditions used in the simulations were: carbon - $71.3 \mathrm{wt} \%$, hydrogen - $5.2 \mathrm{wt} \%$, nitrogen - $1.4 \mathrm{wt} \%$, oxygen - 12.4 to 7.8 wt $\%$, sulfur - 0 to $4.6 \mathrm{wt} \%$, metal concentration - $50 \mathrm{ppm}$, ash - $9.3 \mathrm{wt} \%$, combustion temperature $900^{\circ} \mathrm{C}$, and percent excess air $-50 \%$.

The results shown in Table 4 indicate that lead will react with both sulfur and silica during combustion. At a temperature below $950^{\circ} \mathrm{C}, \mathrm{PbSO}_{4}(\mathrm{~s})$ is the thermodynamically preferred lead compound; however, between $950^{\circ} \mathrm{C}$ and $1000^{\circ} \mathrm{C}, \mathrm{PbSiO}_{4}(\mathrm{~s})$ is the preferred one; and, above $1000^{\circ} \mathrm{C}$, $\mathrm{PbO}(\mathrm{g})$ is the dominating species. These results suggest that silica is thermodynamically capable of capturing lead. However, the existence of sulfur will affect the capture process especially at a temperature below $950^{\circ} \mathrm{C}$. Note that lead does not seem to react with $\mathrm{Al}_{2} \mathrm{O}_{3}$ according to the equilibrium simulation. It should also be pointed out that lead does not show any reactions with $\mathrm{CaO}$ because there are no thermodynamic data available in the literature.

The results shown in Table 5 for cadmium indicate that cadmium will react with $\mathrm{Al}_{2} \mathrm{O}_{3}$ and $\mathrm{SiO}_{2}$ to form $\mathrm{CdAl}_{2} \mathrm{O}_{4}$ (s) and $\mathrm{CdSiO}_{3}$ (s), respectively. It, however, will not react with $\mathrm{CaO}$. The existence of sulfur does not seem to interfere with the reactions according to the equilibrium results shown in the table. These simulation results, again, suggest that silica and alumina have potential to capture cadmium under the combustion conditions. Note that, although not shown, the simulation results for chromium have indicated that the thermodynamically preferred chromium compound 
under the combustion conditions is exclusively $\mathrm{Cr}_{2} \mathrm{O}_{3}$ (s) and no chromium-sorbent compounds are observed. The results suggest that, thermodynamically, the tested sorbents are not expected to chemically absorb chromium during combustion.

Detailed simulation results on $\mathrm{Pb}-\mathrm{S}-\mathrm{SiO}_{2}, \mathrm{Cd}-\mathrm{S}-\mathrm{SiO}_{2}$, and $\mathrm{Cd}-\mathrm{S}-\mathrm{Al}_{2} \mathrm{O}_{3}$ systems are also shown in Figures 2 through 4 . They clearly indicate the effect of temperature on metal speciation during coal combustion with sorbents. For arsenic and selenium, efforts are currently ongoing to collect the necessary thermodynamic data for equilibrium simulations. The results will be reported in the near future.

\section{Experimental Results}

Typical experimental results indicating the effectiveness of metal capture by various sorbents are shown in Tables 6 through 10 for lead, cadmium, chromium, arsenic and selenium, respectively. Note that the results reported in these tables include only the amount captured by bed sorbents, i.e., the amount captured by fly ash sorbents is not included. It is worth pointing out at this point that the amount captured by fly ash sorbents can be significant especially for lime.

The results shown in Table 6 for lead capture indicate that all three sorbents tested are capable of in-bed capturing lead during fluidized bed coal combustion with the average capture efficiency ranging from $44 \%$ to $69 \%$. Bauxite and zeolite appear to have better "bed sorbent" capture efficiencies than lime. Lime, however, has greater "fly ash sorbent" capture efficiency as compared to zeolite and bauxite which will be discussed later. As suggested by equilibrium simulations, the mechanism of lead capture by zeolite appears to be due to the formation of $\mathrm{Pb}_{2} \mathrm{SiO}_{4}(\mathrm{~s})$ and the mechanism of lead capture by bauxite could be due to the formation of the same compound and/or alumino-silica compounds. The mechanism of lead capture by lime, however, is suspected to be due to the "melt capture" as suggested by Linak and Wendt (1993).

For cadmium capture, the results shown in Table 7 indicate that the average "bed sorbent" capture efficiencies associated with the sorbents are similar to those of lead capture by bed sorbents. All three sorbents are seen to be relatively effective with an average capture efficiency being around $60 \%$. The effectiveness of cadmium capture by bauxite and zeolite appears to suggest the formation of $\mathrm{CdAl}_{2} \mathrm{O}_{4}(\mathrm{~s})$ and $\mathrm{CdSiO}_{3}(\mathrm{~s})$ as revealed from equilibrium simulations. The formation of these compounds, however, could not be analytically confirmed due to their low concentrations in the sorbents.

The chromium capture results shown in Table 8 indicate that zeolite and lime are both capable of capturing the metal. The average capture efficiencies are seen to be 31 and $30 \%$ which are much lower than those of lead and cadmium capture by the two sorbents. The mechanisms of chromium capture by these sorbents, however, are not clear at this time. Efforts are currently devoted to analytically identify the chromium state in the sorbents. Note that bauxite was not observed to capture any chromium because the original bauxite contained a high concentration of chromium which continued to vaporize during combustion. The net result was that, in contrast to chromium capture, bauxite gave away chromium during the process. For arsenic and selenium capture, the results shown in Tables 9 and 10 indicate that the average capture efficiencies of these two metals by 
sorbents are generally in the ranges of 13 to $34 \%$, which are relatively low as compared to those of lead and cadmium capture.

One observation worth reporting is that the observed results strongly indicated that the amount of lead, cadmium and arsenic capture by a unit mass of sorbents was roughly proportional to the concentration of the metal in coal. Typical sets of results indicating this trend are shown in Figures 5 through 7. This trend, however, was not observed for chromium and selenium (see Figures 8 and 9). Note that, the observed results have not clearly indicated the effects of sulfur and other coal properties on capture efficiency of the metal capture process. A typical set of results is shown in Figure 10.

As mentioned previously, the results reported in the tables and figures include only the amount of capture by bed sorbents. It was observed that metal capture by "fly ash sorbent" can be very significant for lime and is insignificant for zeolite and bauxite. The results have indicated that, for lime, this "fly ash sorbent capture" can be as high as $200 \%$ as compared to the "bed sorbent capture" especially on arsenic and selenium. The complete results regarding this capture will be reported in the near future. It is also worth reporting that good fluidization is essential in the metal capture process. The metal capture efficiencies were observed to be much lower when the bed was operated under slugging regimes or near fixed bed conditions.

\section{CONCLUSIONS}

This study investigated the potential of employing suitable sorbents to capture toxic trace metals during fluidized bed coal combustion. The observed experimental results indicated that good fluidization operations are essential in the metal capture process. Metal capture by sorbents can be as high as $88 \%$ depending on the metal species and sorbent involved. All three sorbents tested, i.e., bauxite, zeolite and lime, were observed to be capable of effectively capturing lead and cadmium, and zeolite and lime were able to capture chromium. Arsenic and selenium capture by bed sorbents was found to be relatively ineffective. Results from thermodynamic equilibrium simulations suggested the formation of metal-sorbent compounds such as $\mathrm{Pb}_{2} \mathrm{SiO}_{4}(\mathrm{~s}), \mathrm{CdAl}_{2} \mathrm{O}_{4}(\mathrm{~s})$ and $\mathrm{CdSiO}_{3}(\mathrm{~s})$ under the combustion conditions.

\section{NOTATION}

$\mathrm{C}_{\mathrm{b}} \quad$ metal concentration in bed sorbent, ppm

$\mathrm{C}_{\mathrm{c}} \quad$ metal concentration in coal, ppm

$\mathrm{C}_{\mathrm{f}} \quad$ metal concentration in cyclone sorbent, ppm 
$\mathrm{C}_{\mathrm{o}}$ metal concentration in original sorbent, ppm

$\mathrm{d}_{\mathrm{p}} \quad$ particle diameter, $\mathrm{mm}$

$\mathrm{T} \quad$ combustion temperature, ${ }^{\circ} \mathrm{C}$

$\mathrm{U}$ air superficial velocity, $\mathrm{cm} / \mathrm{s}$

$\mathrm{U}_{\mathrm{mf}} \quad$ minimum fluidization velocity, $\mathrm{cm} / \mathrm{s}$

$\mathrm{W}_{\mathrm{b}} \quad$ weight of collected bed sorbent, $\mathrm{g}$

$\mathrm{W}_{\mathrm{f}} \quad$ weight of collected fly ash sorbent, $\mathrm{g}$

$\mathrm{W}_{\mathrm{c}} \quad$ weight of coal, $\mathrm{g}$

$\phi_{b} \quad$ specific capture capacity of bed sorbent, $\mathrm{mg} / \mathrm{Kg}$

$\phi_{\mathrm{f}} \quad$ specific capture capacity of fly ash sorbent, $\mathrm{mg} / \mathrm{Kg}$

$\psi_{\mathrm{b}} \quad$ percent capture by bed sorbent, $\%$

$\psi_{\mathrm{f}} \quad$ percent capture by fly ash sorbent, $\%$

\section{REFERENCES}

Davidson, R. L., Natush, D. F. S., Wallace, J. R., and Evans, C. A., "Trace Element in Fly Ash Dependence of Concentration on Particle Size," Environmental Science \& Technology， 8, 1107 (1974). 
Gao, D. and G. D. Silcox, "The Effect of Treatment Temperature on Metal Recovery from a Porous Silica Sorbent by EPA Method 3050 and by an HF Based Method," Air and Waste, 83, 1004 (1993).

Ho, T. C., C. H. Chen, J. R. Hopper and D. Oberacker, "Metal Capture During Fluidized Bed Incineration of Wastes Contaminated with Lead Chloride," Combustion Science and Technology, 85, 101 (1992).

Ho, T. C., H. T. Lee, H. W. Chu and J. R. Hopper, "Metal Capture by Sorbents During Fluidized Bed Combustion," Fuels Processing Technology, 39, 373 (1994).

Ho, T. C., Incineration Equilibrium IECP, CEP Software Directory, 68 (1996).

Linak, William P. and Jost O. L. Wendt, "Toxic Metal Emissions from Incineration: Mechanisms and Control," Prog. Energy Combust. Sci, 19, 145 (1993).

Oppelt, E. T., "Incineration of Hazardous Waste - A Critical Review," JAPCA, 37, 558 (1987).

Punjak, W. A., M. Uberoi and F. Shadman, "High-Temperature Adsorption of Alkali Vapors on Solid Sorbents," AIChE J., 35, 1186 (1989).

Uberol, M. and F. Shadman, "Sorbents for Removal of Lead Compounds from Hot Flue Gases," AIChE J., 36, 307 (1990). 
Table 1. Sulfur, Chlorine and Target Metals in Coal Samples (\% for $\mathrm{S}$ and $\mathrm{Cl}$; ppm for metals)

\begin{tabular}{lccccccc}
\hline Coal & $\mathrm{S}$ & $\mathrm{Cl}$ & $\mathrm{Cd}$ & $\mathrm{Cr}$ & $\mathrm{Pb}$ & $\mathrm{As}$ & $\mathrm{Se}$ \\
& & & & & & & \\
\hline IBC-101 & 4.4 & 0.1 & 1.1 & 31 & 8 & 2 & 1.5 \\
IBC-102 & 3.3 & 0.0 & 0.8 & 7 & 149 & 32 & 1.3 \\
IBC-106 & 3.8 & 0.0 & 0.2 & 10.4 & 6 & 4.1 & 2.0 \\
IBC-109 & 1.2 & 0.4 & $<0.3$ & 13 & 18 & 6.9 & 1.5 \\
IBC-110 & 4.6 & 0.0 & $<0.4$ & 11 & 10 & 4.7 & 2.5 \\
IBC-111 & 2.0 & 0.0 & $<0.4$ & 14 & 18 & 6.1 & 1.5 \\
IBC-112 & 2.8 & 0.2 & $<0.3$ & 14 & 27 & 3.3 & 1.6 \\
\hline
\end{tabular}


Table 2. Major Composition, Trace Metal Concentration and Fluidization Properties of the Three Tested Sorbents

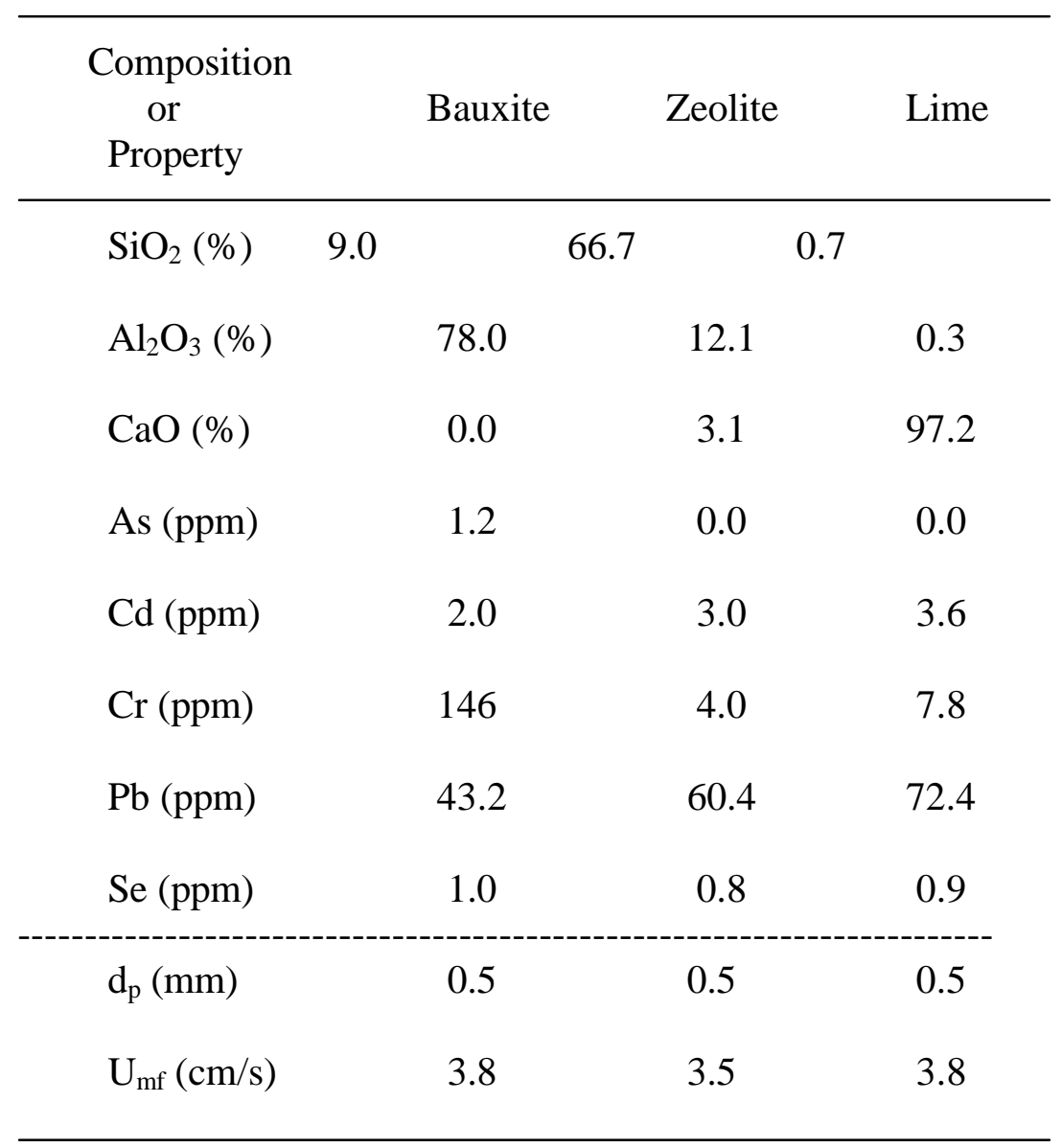


Table 3. Experimental Parameters and Operating Conditions

\begin{tabular}{ll}
\hline Parameter & Range \\
\hline Coal Size & $2.0-2.8 \mathrm{~mm}$ \\
Coal Amount & $60 \mathrm{~g}$ \\
Coal Feed Rate & $0.15-0.3 \mathrm{~g} / \mathrm{min}$ \\
Sorbent Size & $0.4-0.6 \mathrm{~mm}$ \\
Sorbent Amount & $22.5-30 \mathrm{~g}$ \\
Static Sorbent Height & $3-9 \mathrm{~cm}$ \\
Air Flow Rate & $1.2-5 \mathrm{U}$ of Sorbent \\
Combustor Temperature & $900^{\circ} \mathrm{C}$ \\
Combustion Duration & $4.5 \mathrm{hrs}$ \\
\hline
\end{tabular}


Table 4. Equilibrium Simulation Results for Lead with or without Sulfur

\begin{tabular}{|c|c|c|c|c|c|}
\hline \multirow{2}{*}{$\begin{array}{c}\text { Sorbent } \\
\text { Constituent } \\
\mathrm{SiO}_{2}\end{array}$} & & \multirow{2}{*}{$\begin{array}{c}\text { Metal } \\
\mathrm{Pb}\end{array}$} & \multirow{2}{*}{$\begin{array}{c}\text { With or Without } \\
\text { Sulfur } \\
\text { Without } \mathrm{S}\end{array}$} & \multicolumn{2}{|c|}{$\begin{array}{l}\text { Sulfur-Metal-Sorbent } \\
\text { Compound }\end{array}$} \\
\hline & & & & $\mathrm{Pb}_{2} \mathrm{SiO}_{4}(\mathrm{~s})$ & $<1000^{\circ} \mathrm{C}$ \\
\hline & & & & $\mathrm{PbO}(\mathrm{g})$ & $>1000^{\circ} \mathrm{C}$ \\
\hline & & & With S & $\mathrm{PbSO}_{4}(\mathrm{~s})$ & $<950^{\circ} \mathrm{C}$ \\
\hline & & & & $\mathrm{Pb}_{2} \mathrm{SiO}_{4}(\mathrm{~s})$ & $<1000^{\circ} \mathrm{C}$ \\
\hline & & & & $\mathrm{PbO}(\mathrm{g})$ & $>1000^{\circ} \mathrm{C}$ \\
\hline \multirow[t]{4}{*}{$\mathrm{Al}_{2} \mathrm{O}_{3}$} & & $\mathrm{~Pb}$ & Without S & $\mathrm{PbO}(\mathrm{s})$ & $<900^{\circ} \mathrm{C}$ \\
\hline & & & & $\mathrm{PbO}(\mathrm{g})$ & $>900^{\circ} \mathrm{C}$ \\
\hline & & & With S & $\mathrm{PbSO}_{4}(\mathrm{~s})$ & $<950^{\circ} \mathrm{C}$ \\
\hline & & & & $\mathrm{PbO}(\mathrm{g})$ & $>950^{\circ} \mathrm{C}$ \\
\hline \multirow[t]{5}{*}{$\mathrm{CaO}$} & $\mathrm{Pb}$ & & Without S & $<90$ & \\
\hline & & & & $\mathrm{PbO}(\mathrm{g})$ & $>900^{\circ} \mathrm{C}$ \\
\hline & & & With S & $\mathrm{CaSO}_{4}(\mathrm{~s})$ & $>500^{\circ} \mathrm{C}$ \\
\hline & & & & $\mathrm{PbSO}_{4}(\mathrm{~s})$ & $<950^{\circ} \mathrm{C}$ \\
\hline & & & & $\mathrm{PbO}(\mathrm{g})$ & $>950^{\circ} \mathrm{C}$ \\
\hline
\end{tabular}


Table 5. Equilibrium Simulation Results for Cadmium with or without Sulfur

\begin{tabular}{|c|c|c|c|c|c|}
\hline \multirow{2}{*}{$\begin{array}{c}\begin{array}{c}\text { Sorbent } \\
\text { Constituent }\end{array} \\
\mathrm{SiO}_{2}\end{array}$} & & \multirow{2}{*}{$\begin{array}{c}\text { Metal } \\
\mathrm{Cd}\end{array}$} & \multirow{2}{*}{$\begin{array}{l}\text { With or Without } \\
\text { Sulfur } \\
\text { Without S }\end{array}$} & \multicolumn{2}{|c|}{$\begin{array}{l}\text { Sulfur-Metal-Sorbent } \\
\text { Compound }\end{array}$} \\
\hline & & & & $\mathrm{CdSiO}_{3}(\mathrm{~s})$ & $<850^{\circ} \mathrm{C}$ \\
\hline & & & & $\mathrm{CdO}(\mathrm{s})$ & $<1000^{\circ} \mathrm{C}$ \\
\hline & & & & $\mathrm{Cd}(\mathrm{g})$ & $>1000^{\circ} \mathrm{C}$ \\
\hline & & & With S & $\mathrm{CdSO}_{4}(\mathrm{~s})$ & $<800^{\circ} \mathrm{C}$ \\
\hline & & & & $\mathrm{CdO}(\mathrm{s})$ & $<900^{\circ} \mathrm{C}$ \\
\hline & & & & $\operatorname{CdS}(g)$ & $>900$ \\
\hline \multirow[t]{5}{*}{$\mathrm{Al}_{2} \mathrm{O}_{3}$} & & $\mathrm{Cd}$ & Without S & $\mathrm{CdAl}_{2} \mathrm{O}_{4}(\mathrm{~s})$ & $<950^{\circ} \mathrm{C}$ \\
\hline & & & & $\mathrm{CdO}(\mathrm{s})$ & $<1000^{\circ} \mathrm{C}$ \\
\hline & & & & $\mathrm{Cd}(\mathrm{g})$ & $>1000^{\circ} \mathrm{C}$ \\
\hline & & & With S & $\mathrm{CdAl}_{2} \mathrm{O}_{4}(\mathrm{~s})$ & $<950^{\circ} \mathrm{C}$ \\
\hline & & & & $\operatorname{CdS}(g)$ & $>950$ \\
\hline \multirow[t]{5}{*}{$\mathrm{CaO}$} & $\mathrm{Cd}$ & & Without S & & $\varepsilon \mathbb{C} 000$ \\
\hline & & & & $\mathrm{Cd}(\mathrm{g})$ & $>1000^{\circ} \mathrm{C}$ \\
\hline & & & With S & $\mathrm{CaSO}_{4}(\mathrm{~s})$ & $>500^{\circ} \mathrm{C}$ \\
\hline & & & & $\mathrm{CdO}(\mathrm{s})$ & $<900^{\circ} \mathrm{C}$ \\
\hline & & & & $\operatorname{CdS}(g)$ & \\
\hline
\end{tabular}


Table 6. Percentage Lead Capture by Bed Sorbents $\left(\psi_{\mathrm{b}}\right)$

\begin{tabular}{cccc}
\hline CoallSorbent & Bauxite & Zeolite & Lime \\
\hline IBC-101 & 64 & 74 & 75 \\
IBC-102 & 80 & 68 & 16 \\
IBC-106 & 77 & 57 & 67 \\
IBC-109 & 62 & 47 & 49 \\
IBC-110 & 73 & 51 & 36 \\
IBC-111 & 49 & 62 & 32 \\
IBC-112 & 74 & 44 & 22 \\
\hline ------------------------------------------------------------ \\
Average
\end{tabular}


Table 7. Percentage Cadmium Capture by Bed Sorbents $\left(\psi_{\mathrm{b}}\right)$

\begin{tabular}{|c|c|c|c|}
\hline CoallSorbent & Bauxite & Zeolite & Lime \\
\hline IBC-101 & 54 & 52 & 56 \\
\hline IBC-102 & 50 & 58 & 58 \\
\hline IBC-106 & 76 & 72 & 70 \\
\hline IBC-109 & 71 & 88 & 50 \\
\hline IBC-110 & 47 & 58 & 61 \\
\hline IBC-111 & 56 & 30 & 73 \\
\hline IBC-112 & 55 & 49 & 50 \\
\hline Average & 58 & 58 & 60 \\
\hline
\end{tabular}


Table 8. Percentage Chromium Capture by Sorbents $\left(\psi_{\mathrm{b}}\right)$

\begin{tabular}{cccc}
\hline CoallSorbent & Bauxite & Zeolite & Lime \\
\hline IBC-101 & 0 & 4 & 2 \\
IBC-102 & 0 & 26 & 30 \\
IBC-106 & 0 & 22 & 9 \\
IBC-109 & 0 & 37 & 26 \\
IBC-110 & 0 & 66 & 44 \\
IBC-111 & 0 & 10 & 47 \\
IBC-112 & 0 & 54 & 51 \\
Average & $\mathbf{0}$ & $\mathbf{3 1}$ & $\mathbf{3 0}$ \\
\hline
\end{tabular}


Table 9. Percentage Arsenic Capture by Sorbents $\left(\psi_{\mathrm{b}}\right)$

\begin{tabular}{cccc}
\hline CoallSorbent & Bauxite & Zeolite & Lime \\
\hline IBC-101 & 57 & 24 & 27 \\
IBC-102 & 23 & 7 & 31 \\
IBC-106 & 28 & 14 & 23 \\
IBC-109 & 34 & 13 & 12 \\
IBC-110 & 32 & 19 & 28 \\
IBC-111 & 28 & 18 & 23 \\
IBC-112 & 43 & 22 & 24 \\
\hline Average & $\mathbf{3 4}$ & $\mathbf{1 7}$ & $\mathbf{2 4}$ \\
\hline
\end{tabular}


Table 10. Percentage Selenium Capture by Sorbents $\left(\psi_{\mathrm{b}}\right)$

\begin{tabular}{cccc}
\hline CoallSorbent & Bauxite & Zeolite & Lime \\
\hline IBC-101 & 29 & 28 & 24 \\
IBC-102 & 18 & 9 & 16 \\
IBC-106 & 9 & 8 & 10 \\
IBC-109 & 43 & 11 & 12 \\
IBC-110 & 12 & 3 & 12 \\
IBC-111 & 18 & 24 & 22 \\
IBC-112 & 8 & 10 & 12 \\
--------------------15 \\
Average & $\mathbf{2 0}$ & $\mathbf{1 3}$ & $\mathbf{1 5}$ \\
\hline
\end{tabular}




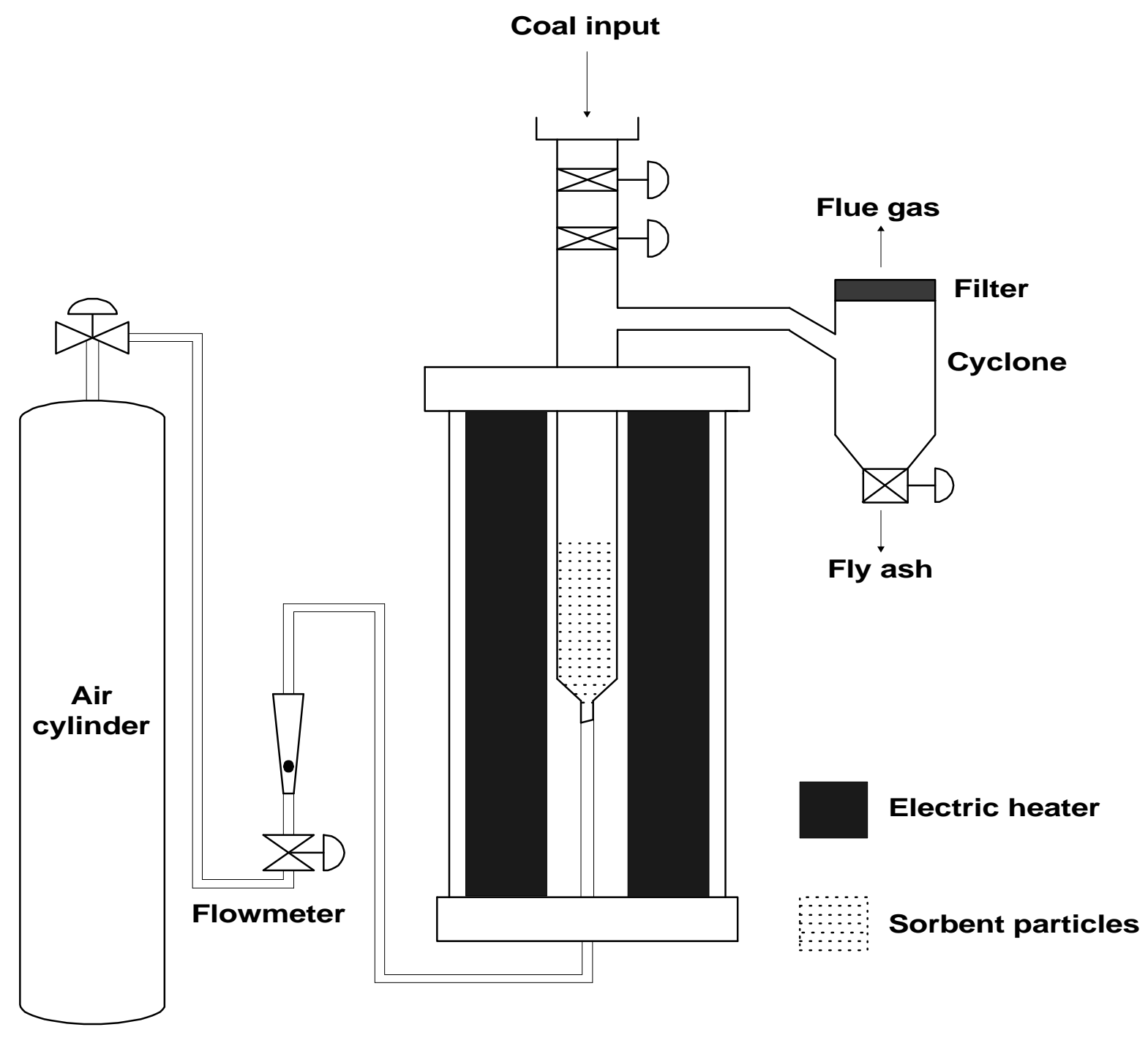

Fig. 1. Fluidized bed coal combustion system. 


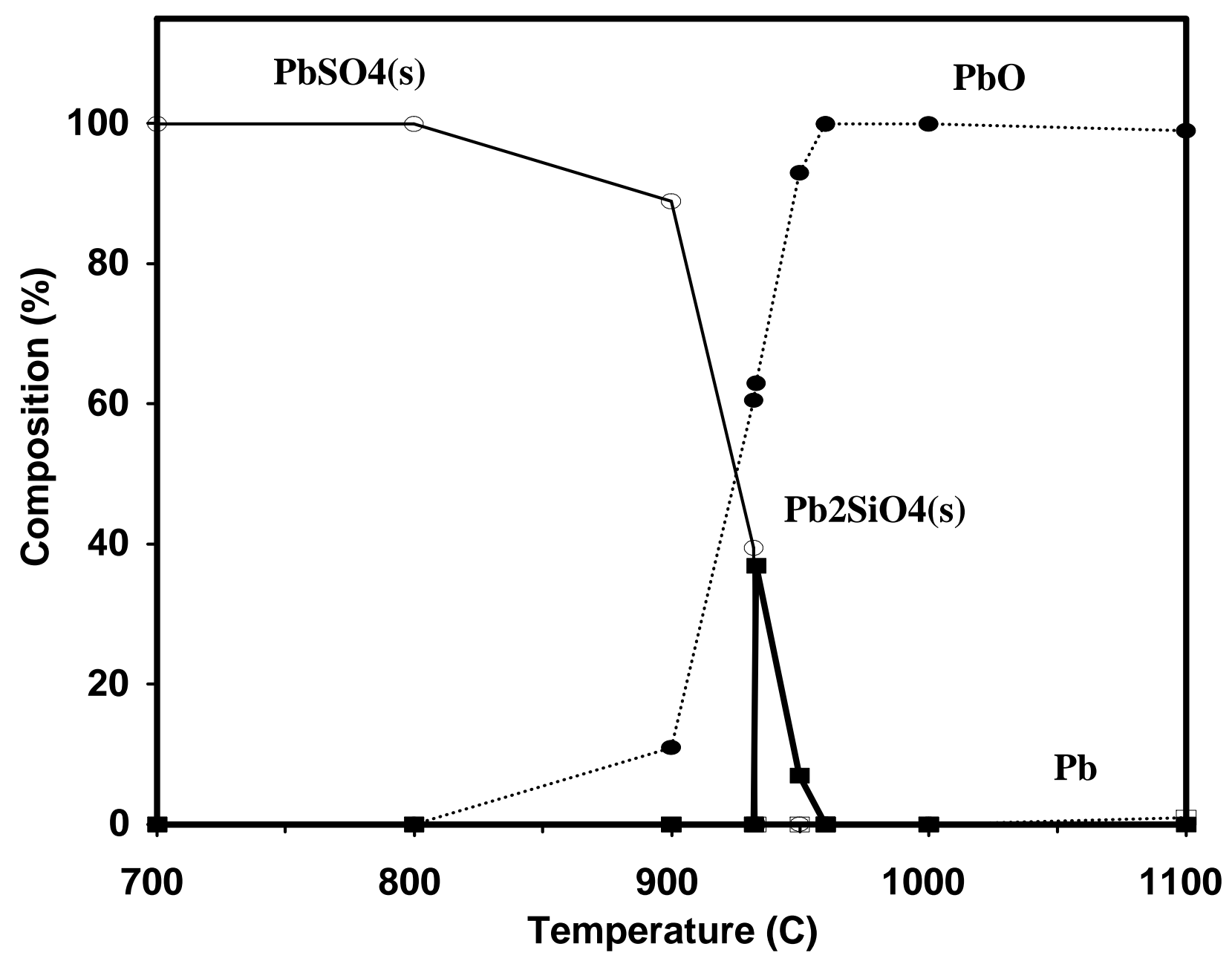

Fig. 2. Simulated lead speciation (System: $\mathrm{Pb}-\mathrm{S}-\mathrm{S}_{\mathbf{i}} \mathrm{O}_{2}$ ). 


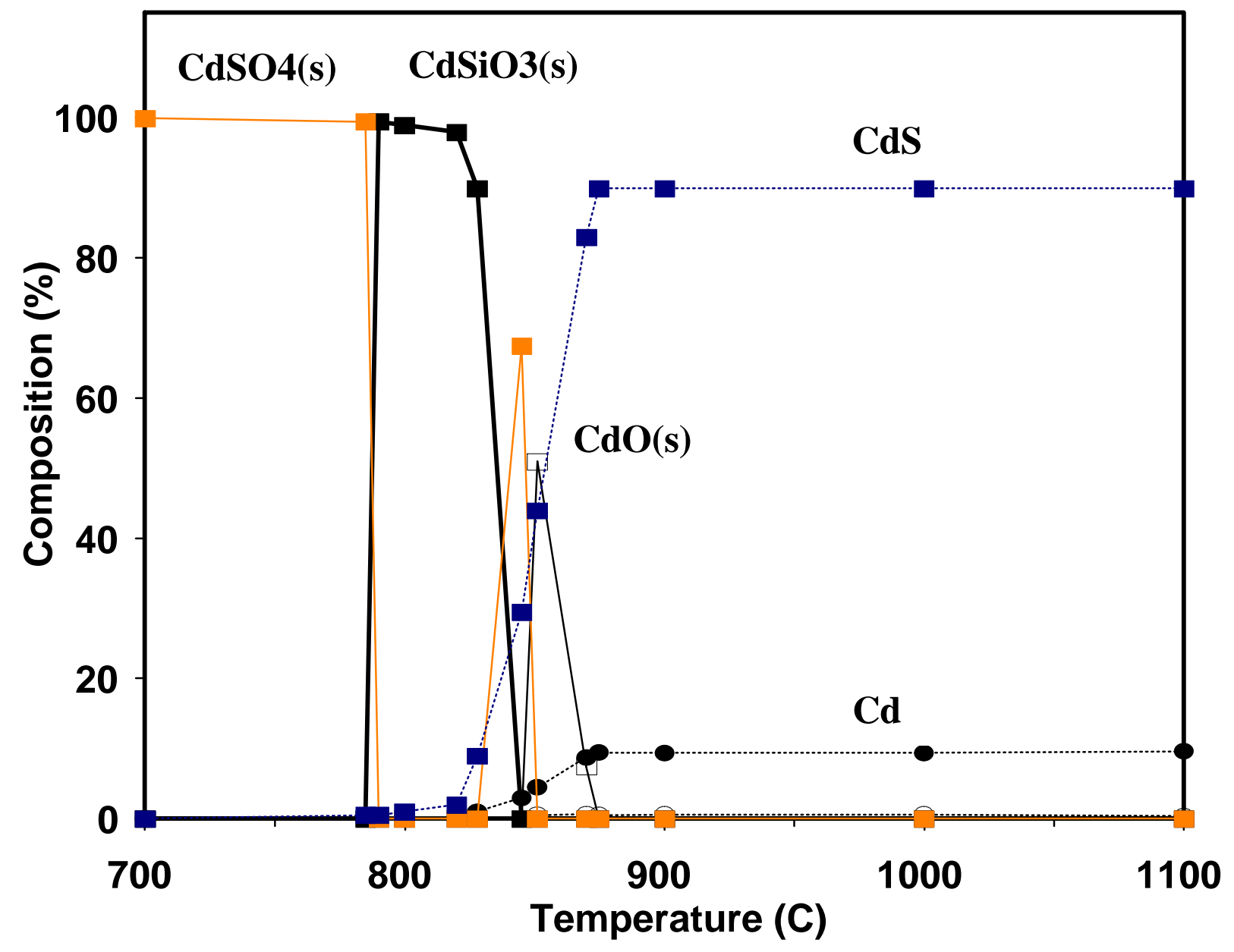

Fig. 3. Simulated cadmium speciation (System: Cd-S-S $\mathrm{S}_{\mathrm{i}} \mathrm{O}_{2}$ ). 


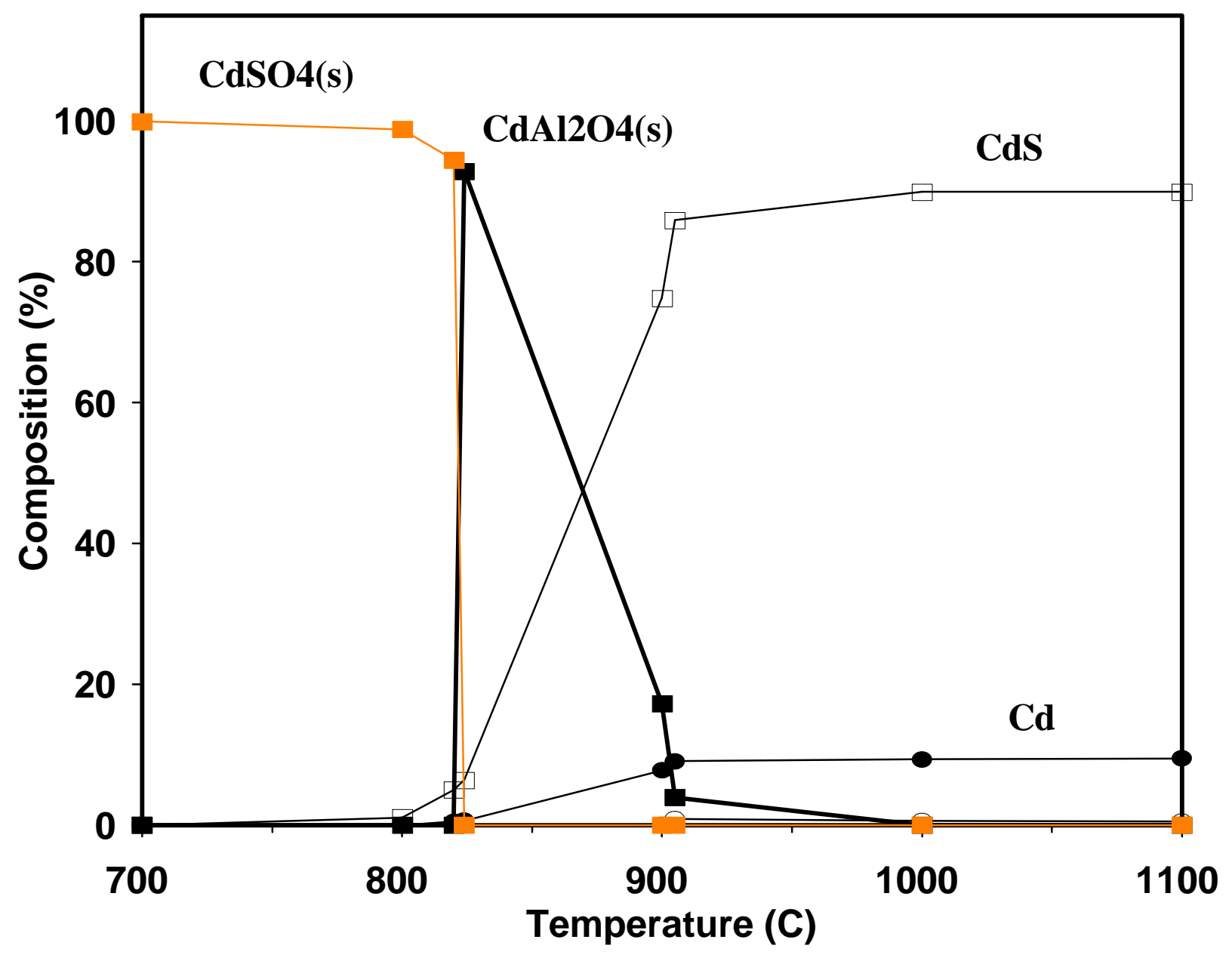

Fig. 4. Simulated cadmium speciation (System: Cd-S- $\mathrm{Al}_{2} \mathrm{O}_{3}$ ). 


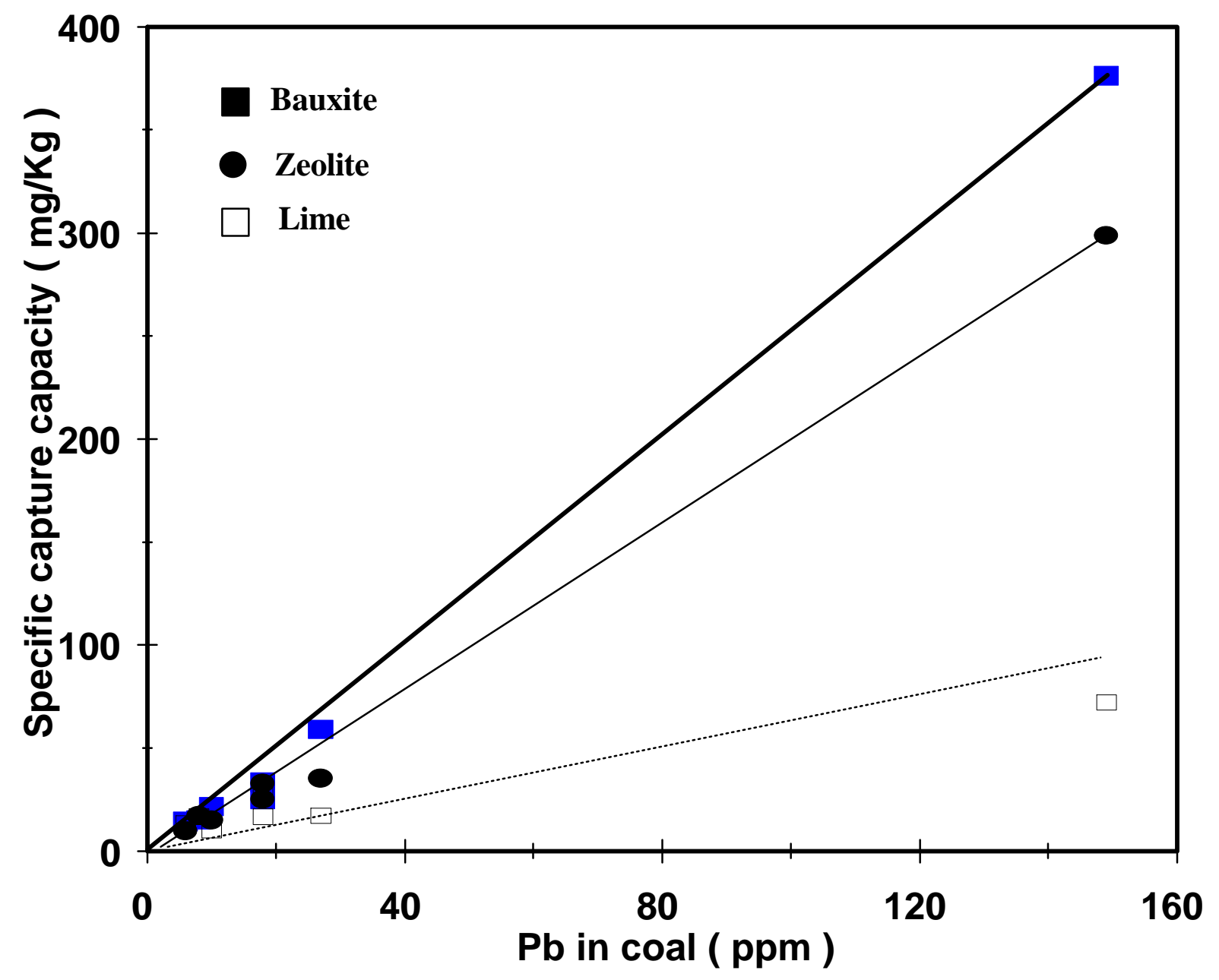

Fig. 5. Specific capture capacity of $\mathrm{Pb}$ by bed sorbents $\left(\phi_{b}\right)$. 


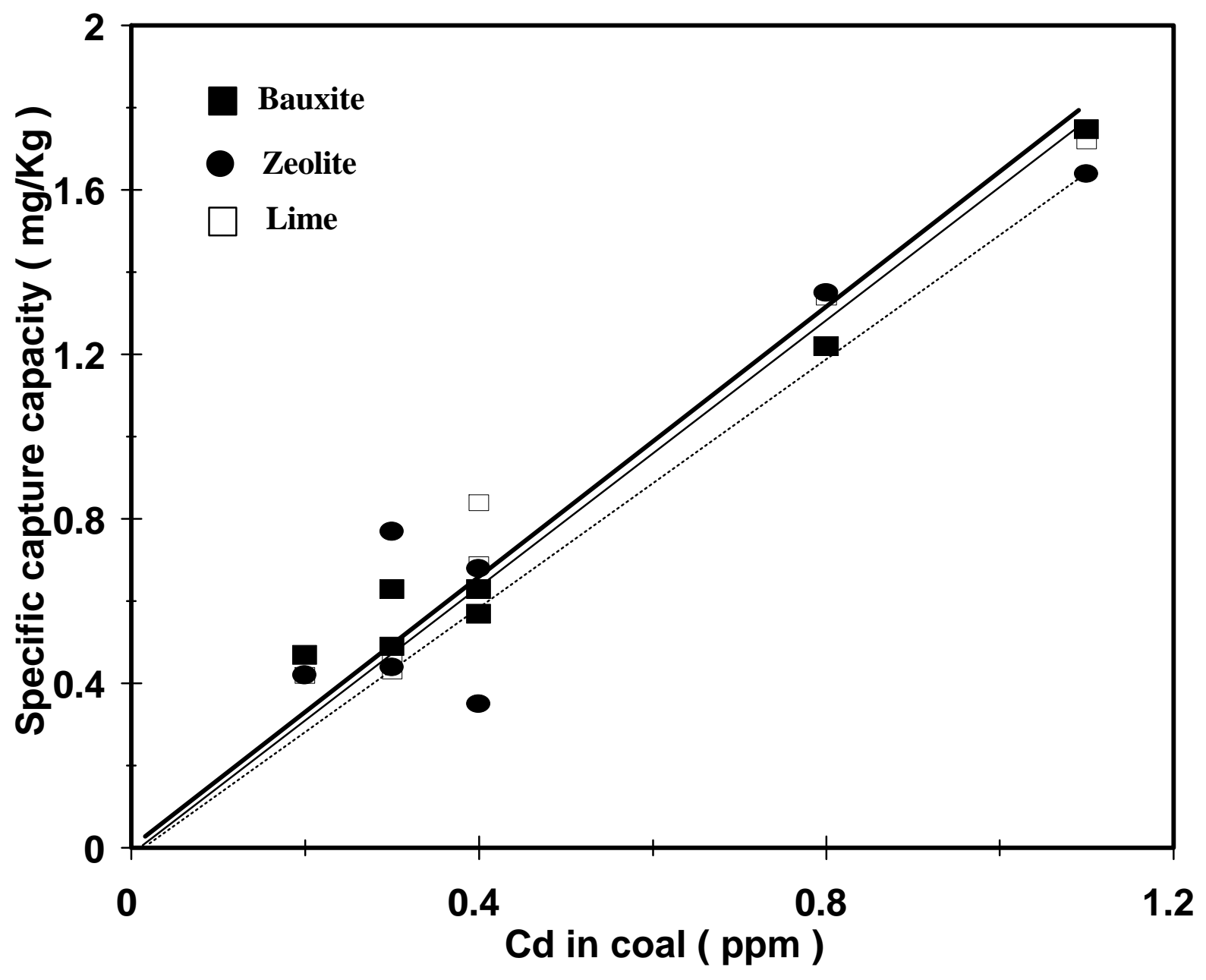

Fig. 6. Specific capture capacity of $\mathrm{Cd}$ by bed sorbents $\left(\phi_{b}\right)$. 


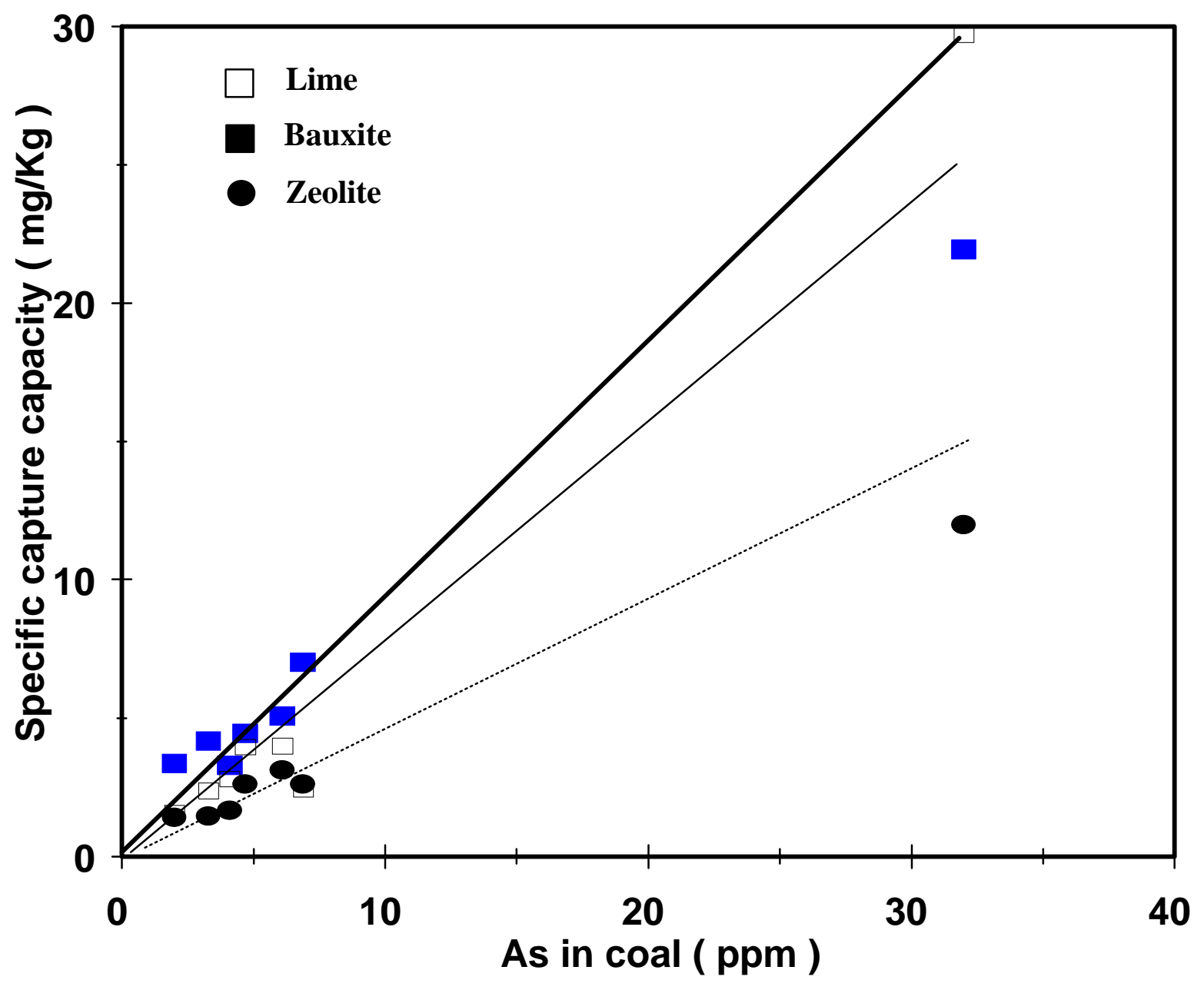

Fig. 7. Specific capture capacity of As by bed sorbents $\left(\phi_{b}\right)$. 


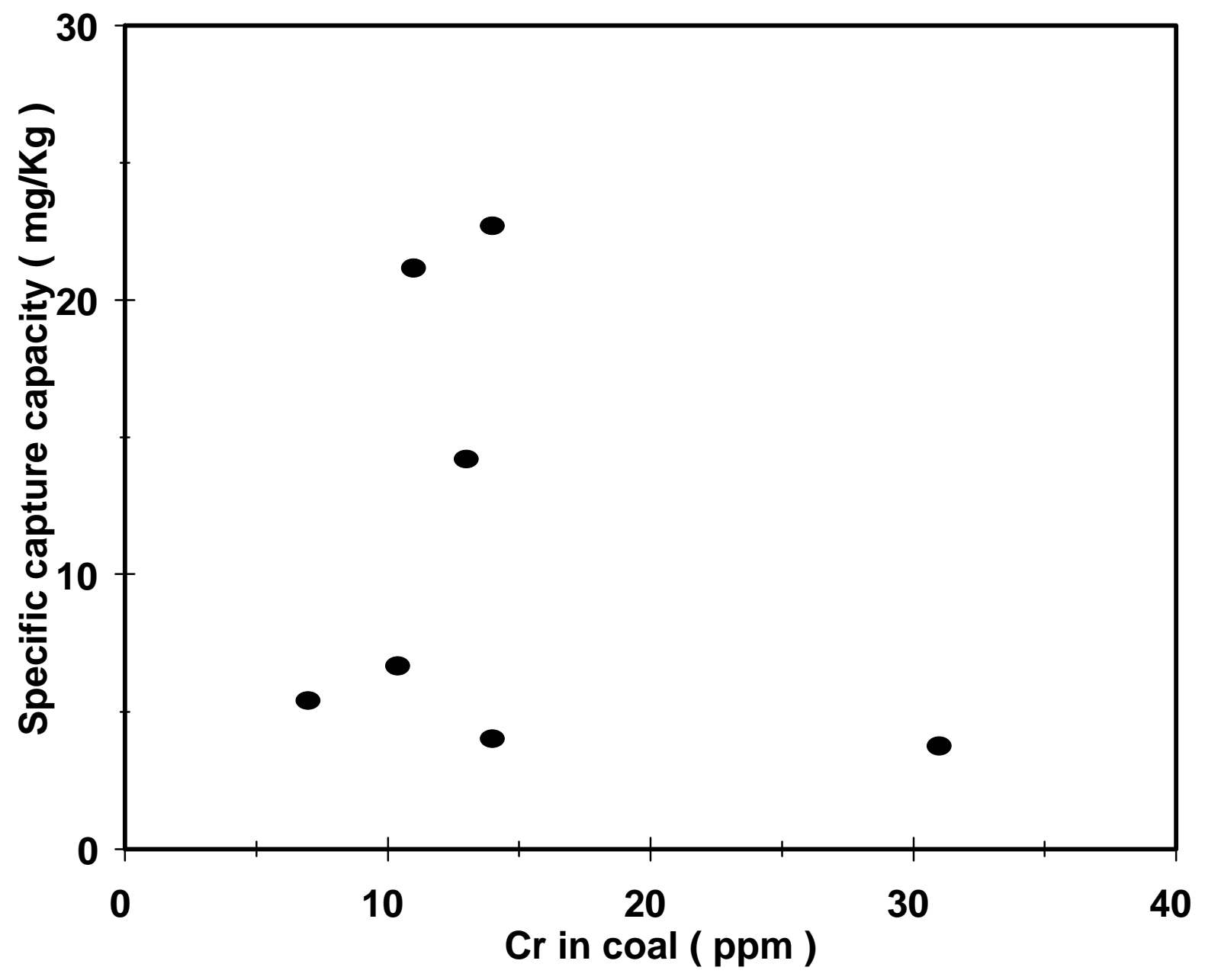

Fig. 8. Specific capture capacity of $\operatorname{Cr}$ by zeolite $\left(\phi_{b}\right)$. 


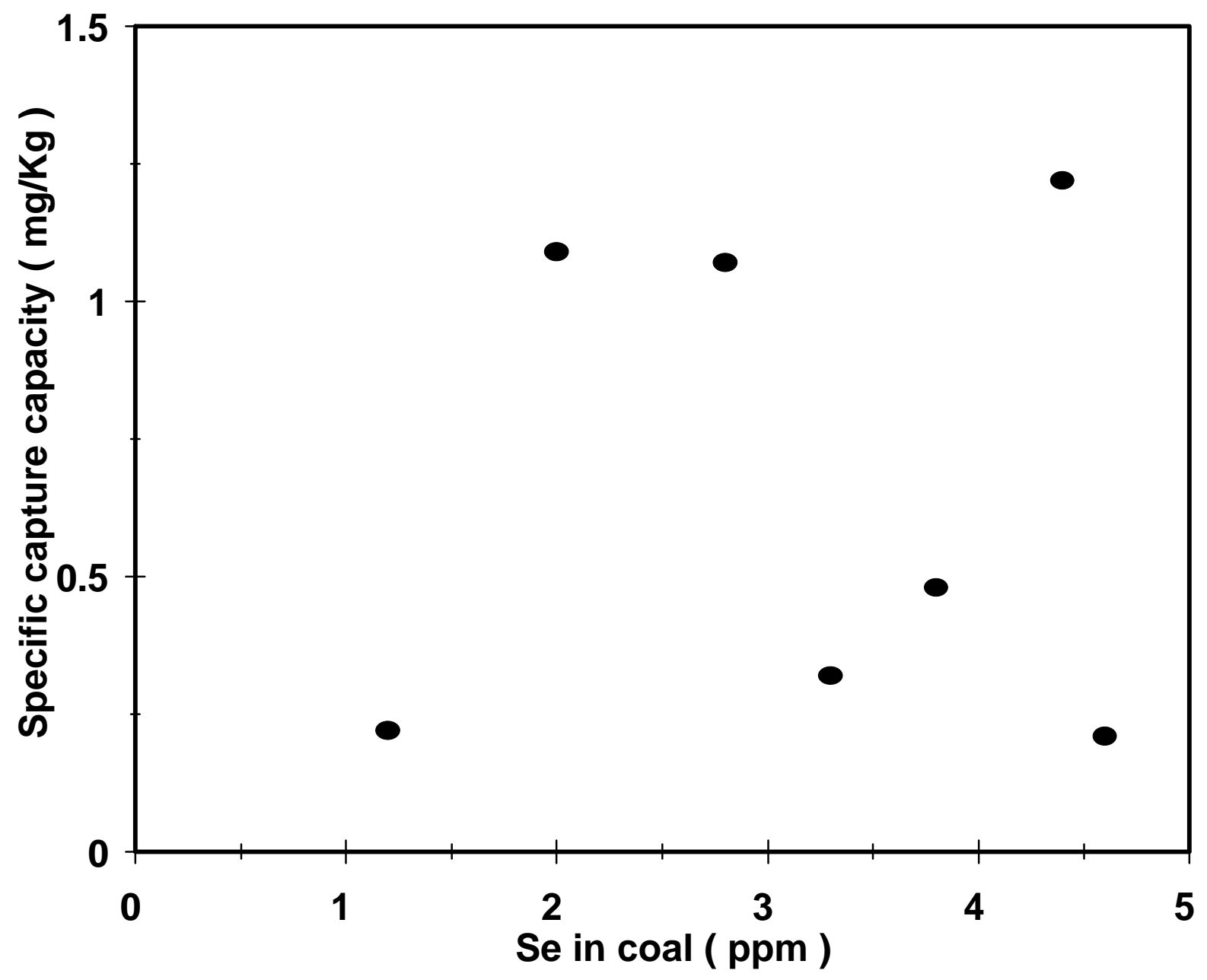

Fig. 9. Specific capture capacity of Se by Zeolite $\left(\phi_{b}\right)$. 


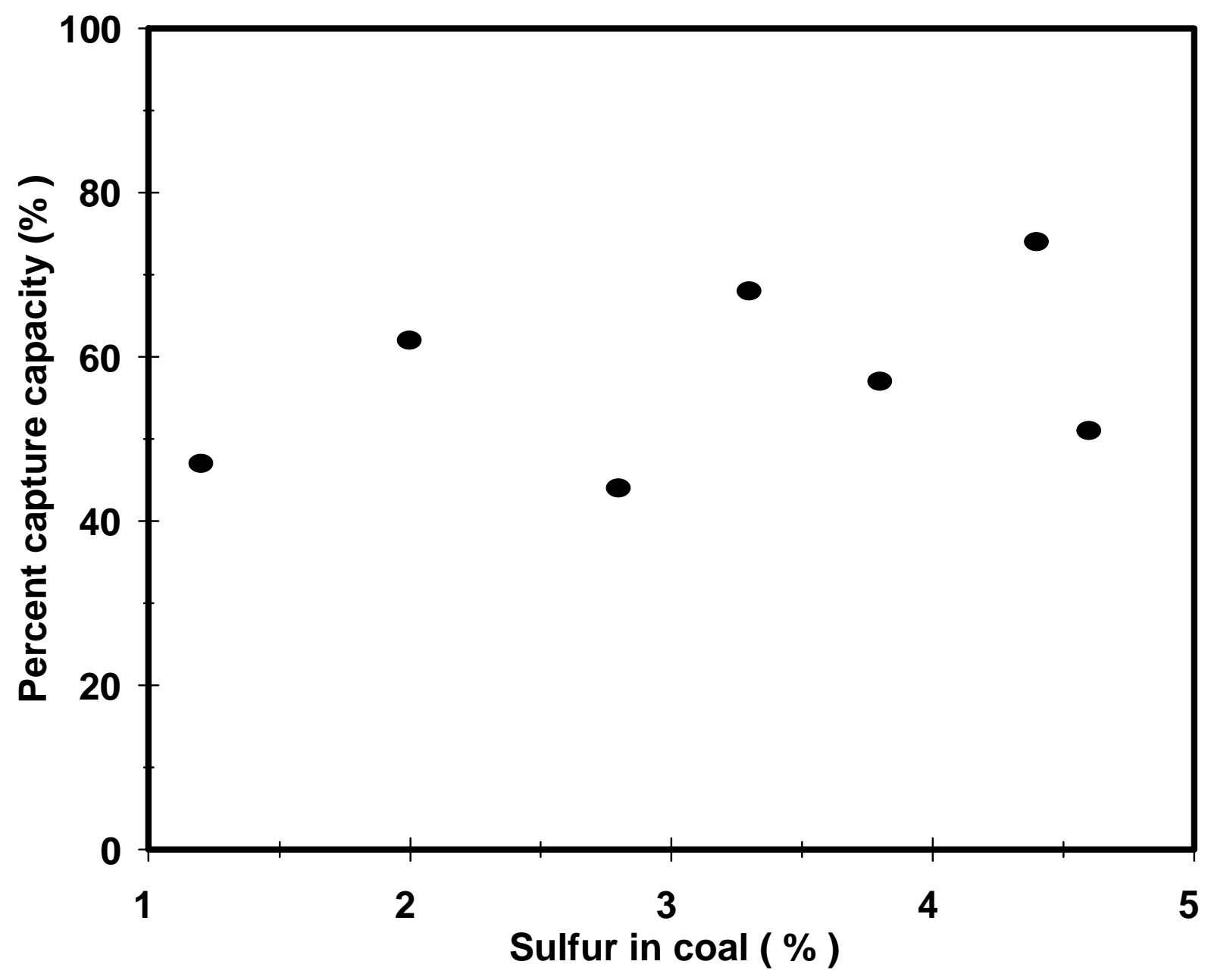

Fig. 10. Percent capture capacity of $\mathrm{Pb}$ by Zeolite $\left(\psi_{\mathrm{b}}\right)$. 